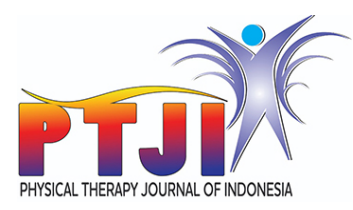

\title{
The Relationship between Physical Activity with Increased Learning Concentration Among Students at Senior High School 3 Denpasar
}

\author{
I Putu Yudi Pramana Putra, ${ }^{1 *}$ M. Widnyana, ${ }^{1}$ I Dewa Gede Alit Kamayoga, ${ }^{1}$ \\ Ni Luh Putu Gita Karunia Saraswati, ${ }^{1}$ Anak Agung Gede Eka Septian'
}

\begin{abstract}
Introduction: Physical activity is any body movement caused by the work of skeletal muscles system and increases the expenditure of effort and energy. The energy is used as fuel to perform motion and function. Nutrition and oxygen throughout the tissue will be better with increased physical condition which showed by increased in the amount of hemoglobin in the blood. Increased concentration will occur when the two energy substances in the human brain effect and fastering body's circular system.

Objective: To determine the relationship between physical activity with increasing concentration on students in learning at senior high school 3 Denpasar.

sampling. This study used an observational method with a cross sectional design. This research collects data from 122 students at senior high school 3 Denpasar which will measure the level of physical activity and concentration.

Results: The results showed that there was a significant relationship between physical activity with increase in learning concentration on students at senior high school 3 Denpasar $(r=0,737 ; p<0,05)$. Conclusion: There is a significant relationship with a positive value between physical activity with an increase in learning concentration on students at senior high school 3 Denpasar. If physical activity increases, the concentration of learning will also increase
\end{abstract}

Methods: The sampling technique in this study was consecutive
'Department of Physical Therapy, College of Medicine, Universitas Udayana, Bali, Indonesia.

\section{*Corresponding to:}

I Putu Yudi Pramana Putra, Department of Physical Therapy, College of Medicine, Universitas Udayana, P.B. Sudirman Street, Denpasar, Bali, Indonesia, 80234; yudipramanaputraa@gmail.com

Received : 2021-08-06 Accepted : 2021-11-01 Published : 2021-12-02

Keywords: concentration, physical activity Cite this Article: Putra, I.P.Y.P., Widnyana, M., Kamayoga, I.D.G.A., Saraswati, N.L.P.G.K., Septan, A.A.G.E. 2021. The Relationship between Physical Activity with Increased Learning Concentration Among Students at Senior High School 3 Denpasar. Physical Therapy Journal of Indonesia 2(2): 41-45. D0I: 10.51559/ptji.v2i2.33

\section{INTRODUCTION}

Today's modern education system requires student who receive education to be able to always focus on doing school assignments that are given, sometimes offten to affect the psychological and physical fatigue conditions of student. That task from the school make students to stay up late and even forget how important food nutrition is afterworking their brains for hours that usually will increasing the risk of problem on body that they will later regret. Adolescence here is a process of stages of growth and development that will naturally be passed by every human being, where adolescence is a transitional period from childhood to adulthood which can also be characterized by secondary sex growth. Growth and development in this phase will be very rapid which is known as the adolescent growth spurt and of course requires a large amount of nutrition. ${ }^{1}$

In the physiological process to be able to understand a learning material, it is necessary to concentrate on the student's brain system as a mediator for saving files in the human body. Concentration is a mechanism of the human body to be able to prepare the senses in responding to and understanding an event that is carried out by the brain as the central nervous system. Concentration is used in almost all human functional activities, such as simple activities that require little concentration, such as walking, sweeping, to activities with high concentration, such as counting and threading a needle. As the concentration increases, a habit system known as CPGs is formed. Central Pattern Generattors (CPGs) is one of the important mechanissem on human body that connect between motoric and sensoric adaptation, CPGs work as a short cut on brain system that knowing activity that already saved and used to do then fastering the proccess of thinking. ${ }^{2}$

According to data from the Indonesian Ministry of Health (2013), it is explained that there is a relationship between the increase in student learning outcomes and the level of concentration they have. In addition, countries with advanced education systems will prioritize concentration as the front base in learning. ${ }^{3}$ In addition, previous study explained that there was an increase in the level of concentration of learning in students after 
carrying out physical activities that support the fitness of the students themselves. ${ }^{4}$

Physical activity has been proven not only as a prevention method, but also what is rarely realized is that regular and physical activity with the good intensity will optimize nutrition management, increase oxygenation in the blood by increasing blood hemoglobin. Hemoglobin is a content that is often used as a reference in measuring the brain's ability to work. ${ }^{5}$

According to Syaifuddin, (2014) in his research that examined the importance of oxygenation in the human brain, $60-70 \%$ of the oxygen we breathe will be used as fuel in the human brain. Muscle is the second heart in the human body, every contraction will help the body to be able to flow nutrients to all body tissues. It has become a common thing that a person's physical fitness level will be determined from how active the person is in carrying out a structured physical activity. ${ }^{6}$

In theories and concepts that have been tested for their validity and reliability, there are several important factors that play a central role in increasing oxygen saturation in the human brain which is related to increasing learning concentration, namely hemoglobin levels in the blood. Hemoglobin is a protein compound that functions as an oxygen transporter in the form of a red blood cell pigment that is rich in iron. In the process of blood circulation, red blood cells will carry oxygen-rich blood to all tissues that need it and the rest of the oxygen metabolism, namely carbon dioxide, will also be transported by hemoglobin to the lungs to be expelled through the exhalation process. Oxygen carried by the blood will be transfused to the brain for processing information. contraction therefore the oxygen concentration in a tissue will affect the movement strength, endurance and power of the resulting movement. ${ }^{7}$ Therefore, there have been many studies that use hemoglobin levels as one of the benchmarks in determining concentration and someone who has a hemoglobin level less than the normal value will usually have complaints such as feeling tired, lethargic, dizzy, decreased appetite, and lack of concentration. ${ }^{8}$

According to research from Yanti, et al. (2017), good hemoglobin levels will affect learning ability. For every $1 \mathrm{~g} / \mathrm{dL}$ increase in hemoglobin, learning achievement will increase 2.3 times, and people who do not have anemia will have a total IQ increase of up to 12.9 points. Disrupted oxygen intake due to decreased hemoglobin levels also causes neurological problems and behavioral disorders such as decreased physical activity, motor skills, social interactions, and impaired concentration. ${ }^{9}$

The relationship between physical activity and learning concentration still requires a lot of research studies, because the relationship between the two variables requires a thorough understanding of the concept of nutrient transport mechanisms and information processing in the brain, especially related to concentration. By concentrating, the body will be able to create a soft movement and increase thinking power in the human brain. Because of this, the researcher wants to explore and research further about the association of the two variables

\section{METHODS}

\section{Research Design}

The research design that has been carried out in this study is a cross sectional research design where the purpose of this study is to prove the relationship between physical activity with the concentration level of student at senior high school 3 Denpasar.

\section{Place and Time of Research}

This research was conducted at senior high school 3 Denpasar between January to February 2020.

\section{Population and Sample}

Total of the population at senior high school 3 Denpasar are 347 students and target sample of this study were all students who were in grade 10 math and science classes at senior high school 3 Denpasar are 122 students.

\section{Sampling Technique}

Accidental sampling and consecutive sampling techniques were used in the sampling procedure in this study.

\section{Research Procedure}

The procedures of this research are: the preparation stage and the implementation stage.

Preparation Phase: (a) Requesting permission from the relevant authorities for the sampling of the senior high school 3 Denpasar; (b) Researchers determine the target population and select respondents according to the inclusion (not medically diagnosed with cognitive impairment and willing to be a research sample by signing an informed consent) and exclusion criteria (not taking medicine to increase concentration levels in the last 1 month and absent and uncooperative during the measurement of hemoglobin levels and learning concentration); (c) The researcher provides an explanation to the sample regarding the purpose, benefits and other important information in order to protect the sample and fulfill the research code of ethics; (d) Population fill in the form of informed consent. 
The implementation phase: (a) Once again in more detail explaining the procedural of data collection to respondents; (b) Measuring student's physical activity by filling the kuesioner and measuring learning concentration by taking hemoglobin levels with Easy Touch GCHb meter; (c) The data obtained will be processed in SPSS and discussed in the discussion of this research.

\section{Data Analysis}

Data analysis using SPSS version 23 software. (1) Descriptive statistics to analyze age, duration of work every day, and length of work, (2) Hypothesis testing using rank spreamens.

Table 1. Characteristics of students in the grade $\mathbf{1 0}$ math and science classes at senior high school 3 Denpasar $(n=122)$

\begin{tabular}{|c|c|c|c|}
\hline \multicolumn{2}{|c|}{ Category } & \multirow{2}{*}{$\begin{array}{l}\mathbf{n} \\
68\end{array}$} & \multirow{2}{*}{$\begin{array}{c}\% \\
55,73 \%\end{array}$} \\
\hline & Men & & \\
\hline Gender & Women & 54 & $44,26 \%$ \\
\hline
\end{tabular}

Table 2. Classification of physical activity of students in the grade $\mathbf{1 0}$ math and science classes at senior high school 3 Denpasar (n = 122)

\begin{tabular}{lccc}
\hline \multicolumn{1}{c}{ Category } & Score & $\mathbf{n}$ & $\%$ \\
\hline Moderate Physical Activity & $\geq 12$ & 105 & $86,1 \%$ \\
Light Physical Activity & $11-11,9$ & 9 & $7,4 \%$ \\
Heavy Physical Activity & $8-10,9$ & 8 & $6,5 \%$ \\
\hline
\end{tabular}

Table 3. Results of the distribution of student learning concentration among the students in the grade 10 math and science classes at senior high school 3 Denpasar $(n=122)$

\begin{tabular}{lccc}
\hline Variable & Mean \pm SD & Min-Maks & IK 95\% \\
\hline Learning Concentration & $69,0 \pm 7,0$ & $50,0-88,9$ & $67,73-70,28$ \\
\hline
\end{tabular}

Table 4. Overview of student learning concentration among the students in the grade 10 math and science classes at senior high school 3 Denpasar $(n=122)$

\begin{tabular}{lccc}
\hline $\begin{array}{c}\text { Learning } \\
\text { Concentration }\end{array}$ & Score & $\mathbf{n}$ & \% \\
\hline Low & $25-50$ & 2 & $1,6 \%$ \\
\hline Medium & $51-76$ & 105 & $86,1 \%$ \\
\hline High & $77-100$ & 15 & $12,3 \%$ \\
\hline
\end{tabular}

Table 5. Relationship between physical activity levels and learning concentration among the students in the grade 10 math and science classes at senior high school 3 Denpasar

\begin{tabular}{ccc}
\hline \multicolumn{1}{c}{ Variable } & r & p value \\
\hline $\begin{array}{l}\text { Physical Activity Levels and Learning } \\
\text { Concentration on Student }\end{array}$ & 0,737 & $<0,001^{\star}$ \\
\hline
\end{tabular}

\section{RESULTS}

Characteristics of students of the grade 10 math and science classes at senior high school 3 Denpasar. From the data that show on Table 1, it can be clearly seen that there is a difference in the number of sexes between men and women in the grade 10 math and science classes at senior high school 3 Denpasar, male totaling 68 students or $55.73 \%$ while female 54 students or $44.26 \%$ of the total number of students. the whole sample. Based on observations made in the field at the time of data collection, there was no significant effect between gender and physical activity due to an even distribution in both groups.

Characteristics of physical activity of the grade 10 math and science classes at senior high school 3 Denpasar (Table 2). Although the dominance of extracurricular activities at school, most students stated that they had only one activity, but from data collection in the field it was found that there were additional physical activities which caused 105 of the total sample to be in moderate physical activity where a presentation of $86.1 \%$ was obtained.

Concentration of Studying in the grade 10 math and science classes at senior high school 3 Denpasar. The results of the research that has been done regarding the concentration of learning in student are presented in Table 3 . From the data that show on tabel 3, it can be seen that the average concentration of learning in adolescent students in the grade 10 math and science classes at senior high school 3 Denpasar is $69.0(\mathrm{SD}=70)$. The lowest value is 50.0 and the highest value is 88.9. The estimated $95 \%$ confidence value is believed to be at a value of 67.73-70.28. And from the data it can also be seen that most of the students have a high level of concentration with a percentage of $86.1 \%$ which is interpreted as having a moderate learning concentration (Table 4).

The relationship between physical activity with learning concentration among students in the grade 10 math and science classes at senior high school 3 Denpasar. Based on the results of the Pearson Product Moment correlation test with a 95\% confidence level $(\alpha=0.05)$, the results obtained are presented in Table 5 . There is a significant positive relationship between hemoglobin levels and learning concentration in students in the grade 10 math and science classes at senior high school 3 Denpasar $(r=0.737$; $\mathrm{p}$ value $<0.001)$. This indicates that the higher the hemoglobin level, the higher the concentration of learning in young women and vice versa if the hemoglobin level of the young women is low, the learning concentration will be lower. Because the $\mathrm{p}$ value $<0.05$, it can be concluded that the null hypothesis (Ho) is rejected and the alternative hypothesis $(\mathrm{Ha})$ is accepted. 


\section{DISCUSSION}

The relationship between physical activity and increased learning concentration among students in the grade 10 math and science classes at senior high school 3 Denpasar. Physical activity is an important component that functions not only to increase the immune system but also as a basic method of maintaining physical fitness. Working muscles will increase tissue circulation and body metabolism. So that the transport of nutrients will be more easily reached to the tissues that need it. ${ }^{10}$

In this study, the measurement of physical activity was carried out by conducting interviews and filling out questionnaires regarding routine activities carried out at school, especially the number of extracurricular activities involving physical activity. From the research, it was found that the majority of students had more than one extracurricular or physical activity at school. There is a problem caused by this group where student who take part in more than one type of extracurricular activity will tend to find it more difficult to divide their time in participating in the learning process, doing schoolwork, extracurricular activities assignments and time to sleep. Because physical activity that is done excessively will cause tension in the muscles, causing difficulty sleeping, which will cause a person's focus and attention to be hampered when studying a material. ${ }^{11}$

The level of concentration obtained in students is in the medium category. These results were obtained because in this study several other factors, both internal and external factors that could affect the learning concentration of young women, did not collect the data. These factors include internal factors which include health status, attention, interest, readiness, and motivation to learn. ${ }^{12}$

Hemoglobin as one of the variables that functions to measure the level of learning concentration in students at the grade 10 math and science classes at senior high school 3 Denpasar is still in the normal range, namely $12 \mathrm{~g} / \mathrm{dL}$ as many as 105 people (86\%), with the lowest value of hemoglobin levels being 8.9 and the highest value is 16.3 .

Hemoglobin levels in the body are not only influenced by internal factors but also external factors, one of which is parental income. The food consumed by student is very dependent on the type of food served in the family so that it is related to the amount of funds available to purchase family food..$^{13}$

The results of this study indicate that there is a significant relationship between physical activity and learning concentration in student in the grade
10 math and science classes at senior high school 3 Denpasar. The strength of the relationship formed indicates a strong relationship with the interpretation of the relationship being positive.

The results of this study are supported by Yanti, et al., 2019, where their research explains that low levels of physical activity will result in a reduced amount of oxygen carried so that the energy produced from the body's metabolism decreases. ${ }^{9}$ If the metabolic process is not optimal, the need for energy for the learning process is impaired. Low hemoglobin levels in children will reduce learning abilities, concentration and endurance. As a result, indirectly affect the value of lessons and student achievement. Concentration in following the learning process at school is very important for students, because a good concentration will determine students' abilities and determine whether or not students advance to a higher level. ${ }^{14}$

According to Thalanjeri, et al. (2016) explained that the lack of iron due to decreased physical activity not only produce deficits in memory or learning capacity and motor skills, but also emotional and psychological problems. ${ }^{15}$ By increasing the physical activity of student students will be able to increase learning concentration and in the end there will be harmony between physical fitness and physiological fitness which of course will be able to increase the learning ability and achievement of students at the grade 10 math and science classes at senior high school 3 Denpasar.

\section{CONCLUSION}

There is a significant relationship with a positive value between physical activity with an increase in learning concentration on students at the grade 10 math and science classes at senior high school 3 Denpasar. If physical activity increases, the concentration of learning will also increase.

\section{CONFLICT OF INTEREST}

No conflict of interest is decleared.

\section{FUNDING}

None.

\section{AUTHOR CONTRIBUTIONS}

IPYPP conceived the study design, data collection, data analysis, and drafted manuscript; MW and LPGKS drafted and translated the manuscript; IDGAK and AAGEK drafted and revised the manuscript. 


\section{REFERENCES:}

1. Anggraini DI, Damayanti AS. Sarapan Meningkatkan Prestasi Belajar Pada Anak Usia Sekolah. Jurnal Majority. 2017;6(2):115-9.

2. Yanti D, Irwanto I, Wibowo A. Pengaruh Kadar $\mathrm{Hb}$ Terhadap Prestasi Belajar Anak Usia Sekolah Kelas Ii-Vi Di Sdn Sonoageng 6 Prambon Nganjuk. The Indonesian Journal of Public Health. 2017;12(1):97-105.

3. KKR I. Riset Kesehatan Dasar (RISKESDAS) 2013: Jakarta: Badan Penelitian dan Pengembangan Kesehatan Kementerian Kesehatan, Republik Indonesia; 2013. Available:[Available from: http://www depkes go id/ resources/download/general/HasilRiskesdas2013 pdf.

4. Dumilah PRA, Sumarmi S. Hubungan Kejadian Anemia Dengan Prestasi Belajar Siswi Di SMP Unggulan Bina Insani. Amerta Nutrition. 2017;1(4):331-40.

5. Kisner C, Colby LA, Borstad J. Therapeutic exercise: Foundations and techniques: Fa Davis; 2017.

6. Syaifuddin H. Anatomi Fisiologi Untuk Keperawatan dan Kebidanan. Jakarta Penerbit Buku Kedokteran EGC. 2012.

7. Ikawati MPD. Upaya meningkatkan konsentrasi belajar siswa KMS (Kartu Menuju Sejahtera) menggunakan konseling kelompok bagi siswa. Psikopedagogia Jurnal Bimbingan dan Konseling. 2015;4(2):158-64.

8. Kusmiyati Y, Meilani N, Ismail S. Kadar hemoglobin dan kecerdasan intelektual anak. Kesmas: Jurnal Kesehatan Masyarakat Nasional (National Public Health Journal). 2013;8(3):109-14.
9. Yanti D, Irwanto I, Wibowo A. Pengaruh Kadar $\mathrm{Hb}$ Terhadap Prestasi Belajar Anak Usia Sekolah Kelas Ii-Vi Di Sdn Sonoageng 6 Prambon Nganjuk. The Indonesian Journal of Public Health. 2017;12(1):97-105.

10. Sari EN, Handayani L, Saufi A. Hubungan Antara Umur dan Masa Kerja dengan Keluhan Musculoskeletal Disorders (MSDs) pada Pekerja Laundry. Jurnal Kedokteran dan Kesehatan. 2017;13(2):183-94.

11. Yolanda AA, Wuryanto MA, Kusariana N, Saraswati LD. Hubungan Aktivitas Fisik, Screen Based Activity Dan Sleep Hygien Dengan Kualitas Tidur Pada Remaja Usia 15-18 Tahun (Studi pada Siswa di SMA Negeri 1 Ungaran). Jurnal Kesehatan Masyarakat (Undip). 2019;7(1):123-30.

12. Walgito B. Belajar dan Faktor-Faktor Yang mempengaruhinya: Jakarta. Rineka Cipta. 2010.

13. Zulaekah S, Kusumawati Y, Nugraheni R, Astuti RAT. Hubungan Tingkat Sosial Ekonomi Keluarga dan Pengetahuan Tentang Anemia dengan Perilaku Konsumsi FE Remaja. 2017.

14. Watuna P, Mantik MF, Gunawan S. Perbedaan Kadar Hemoglobin Antara Anak Usia Sekolah Yang Berprestasi Dan Yang Kurang Berprestasi. e-CliniC. 2015;3(1).

15. Thalanjeri P, Karanth H, Shankar V, Kutty K. Impact of iron deficiency anemia on cognition of school children of South India. Indian J Clin Anat Physiol. 2016;3:135-8.

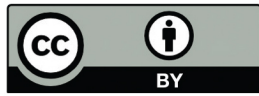

This work is licensed under a Creative Commons Attribution 